\title{
Role of zooplankton in the mesoscale distribution of surface dimethylsulfide concentrations in the Gulf of St. Lawrence, Canada
}

\author{
Guy Cantin $^{1,2, *}$, Maurice Levasseur ${ }^{1}$, Michel Gosselin $^{2}$, Sonia Michaud $^{1}$ \\ ${ }^{1}$ Institut Maurice-Lamontagne, Ministère des Pêches et des Océans, CP 1000, Mont-Joli, Québec, Canada G5H 3Z4 \\ ${ }^{2}$ Département d'océanographie, Université du Québec à Rimouski, 300, Allée des Ursulines, Rimouski, \\ Québec, Canada G5L 3A1
}

\begin{abstract}
We investigated the influence of mesozooplankton grazing on the distribution of dimethylsulfide (DMS) and its metabolic precursor dimethylsulfoniopropionate (DMSP) in the Gulf of St. Lawrence in August 1993. The horizontal distributions of DMS, DMSP, phytoplankton, microzooplankton, and mesozooplankton were determined over a grid of 79 stations covering $41000 \mathrm{~km}^{2}$ Phytoplankton biomass was low (mean $=0.37 \mu \mathrm{g} \mathrm{chl} \mathrm{a} \mathrm{l}^{-1}$ ) and the community was dominated by unidentified flagellates. Prymnesiophyceae, Chrysophyceae, and Dinophyceae. Maximum plankton biomass and DMSP were found in the western portion of the grid influenced by the outflow of the St. Lawrence Estuary va the Gaspé Current. Surface concentrations of particulate DMSP (DMSP $)$ ), dissolved DMSP (DMSP $_{\mathrm{d}}$ ), and DMS ranged from 6 to $117 \mathrm{nM}, 1.7$ to $23.1 \mathrm{nM}$, and $<0.9$ to $9 \mathrm{nM}$, respectively. The surface concentrations of $\mathrm{DMSP}_{\mathrm{p}}$ and $\mathrm{DMSP}_{\mathrm{d}}$ were positively correlated with the abundances of several phytoplankton species belonging to the classes Dinophyceae. Prymnesiophyceae, and Prasinophyceae and with ciliated protozoans, the dommant microzooplankton group. Among the groups showing significant correlation with DMSP ${ }_{p}$. Gyrodinium aureolum and Chrysochromulina spp. were the only species to represent a substantial part of the biomass. The distribution of DMS was not statistically related to the distribution of phytoplankton and microzooplankton. We also found no significant correlations between the distribution of DMSP. DMS, and the abundance of mesozooplankton. Results from 2 shipboard bioassay experiments with Calanus finmarchicus, the dominant mesozooplankton species, indicate no or low grazing activity $\left(0\right.$ and $0.18 \mathrm{ng} \mathrm{chl} a$ ind.$\left.^{-1} \mathrm{~h}^{-1}\right)$ and low accumulation rates of DMSP (5 and 8.9 pmol ind. ${ }^{-1} \mathrm{~h}^{-1}$ ), and of DMS $\left(0\right.$ and $7.7 \mathrm{pmol}$ ind.$^{-1} \mathrm{~h}^{-1}$ ). When extrapolated to the field conditions, these results indicate that the population of $C$. finmarchicus may have increased ambiant concentrations of DMSP and DMS at maximum rate of $5 \mathrm{pmol}^{-1} \mathrm{~h}{ }^{\prime}$. Mesozooplankton grazing apparently played a minor role in DMSP $\mathrm{d}_{\mathrm{d}}$ and DMS accumulation in the Gulf during the cruise. This suggests that the importance of mesozooplankton in the dynamics of DMSP and DMS may vary in time and space depending on the prevailing food web, traditional versus microbıal.
\end{abstract}

KEY WORDS: DMSP DMS Phyloplankton Microzooplankton Mesozooplankton Calanus finmarchicus

\section{INTRODUCTION}

In remote oceanic regions, marine emissions of dimethylsulfide (DMS) are thought to play an important climatic role by increasing the absorption and scattering of solar radiation and by providing cloud

-E-mail:g_cantin@qc.dfo.ca

(1) Inter-Research 1996

Resale of full article not permitted condensation nuclei (Charlson et al. 1987. Hegg et al. 1991, Lawrence 1993) DMS is produced by the enzymatic cleavage of dimethylsulfoniopropionate (DMSP) (Cantoni \& Anderson 1956), a solute found in many microalgae species (Vairavamurthy et al. 1985, Keller et al. $1989 \mathrm{a}$, b). At least 1 marine phytoplankton species, Phaeocystis sp., is able to enzymatically convert dissolved DMSP (DMSP ( $_{\text {) }}$ into DMS (Stefels \& van Boekel 1993). For many species, however, DMSP 
appears to be released during the senescent phase of growth or at cell autolysis (Turner et al. 1988, Keller 1991, Matrai \& Keller 1994), and is then converted into DMS by bacteria (Kiene \& Service 1991, Kiene 1992, Wolfe \& Kiene 1993, Wolfe et al. 1994). Bacterial degradation, photo-oxidation, and sea-air ventilation represent 3 major sinks for DMS (Brimblecombe \& Shooter 1986, Wakeham et al. 1987, Zeyer et al. 1987 , Kiene \& Bates 1990, Thompson et al. 1990, Andreae et al. 1994, Bates et al. 1994).

In addition, zooplankton may play a significant role in the dynamics of DMS production in seawater. Dacey \& Wakeham (1986) demonstrated that the addition of copepods to a phytoplankton culture increased the production rate of DMS by as much as 24 times. Leck et al. (1990) reported a positive correlation between the distribution of copepod biomass and DMS concentrations over an annual cycle in the Baltic Sea. More recently, Levasseur et al. (1994) showed that Limacina helicina, a common suspension-feeding pteropod in arctic and sub-arctic waters, could also stimulate DMSP $_{d}+$ DMS production. Attempts to relate DMS distribution to zooplankton abundance have not always been successful. In the Gulf of Maine, Matrai \& Keller (1993) found no relationship between the distribution of DMS and the abundance of mesozooplankton. In addition, results from recent studies conducted in mesocosms indicated that the removal (by filtration) of the mesozooplankton component of the plankton community had no effect on DMS production (Kwint \& Kramer 1995). These inconsistencies suggest that the effect of mesozooplankton grazing on DMS production may vary in time and space, probably in response to changes in the abundance and type of prey encountered in the marine environment.

Some recent studies suggest that microzooplankton may also play an important role in DMS dynamics. Belviso et al. (1990) demonstrated that ciliates grazing on small flagellates $(<10 \mu \mathrm{m})$ and small Dinophyceae $(\sim 20 \mu \mathrm{m})$ may significantly increase DMS production. Subsequently, they suggested that organisms in the 10 to $200 \mu \mathrm{m}$ size fraction (mostly microzooplankton) were responsible for the DMSP and DMS production in the tropical Atlantic Ocean (Belviso et al. 1993) Studies have also shown that grazing of the heterotrophic dinoflagellate Oxyrrhis marina on the coccolithophore Emiliania huxleyi may significantly increase DMSP and DMS production (Malin et al 1994, Wolfe et al. 1994)

The goal of the present study was to investigate the co-distribution of DMSP and DMS with phytoplankton, microzooplankton, and mesozooplankton in the Gulf of St. Lawrence in summer. Bottle incubation experiments with Calanus finmarchicus, the dominant mesozooplankton species in the study area, were conducted on the ship to gain additional insights into the influence of zooplankton on DMS dynamics in this system.

\section{MATERIALS AND METHODS}

Study area and sampling. A grid of 79 stations located in the Gulf of St. Lawrence was sampled between 4 and 11 August 1993 on a 24 h basis (Fig. 1). At each station, surface water temperature was measured with a mercury thermometer, and a $250 \mathrm{ml}$ bottle was filled with surface water for subsequent determination of salinity on a Guildline Autosal model 8400 . Water samples for chemical and biological analyses were then collected at $1 \mathrm{~m}$ depth with a 12 l Niskin bottle. All water samples were prescreened through $233 \mu \mathrm{m}$ Nytex mesh to remove large zooplankton. Every day around noon, vertical profiles of temperaLure, salinity, and in vivo fluorescence were conducted from the surface to $100 \mathrm{~m}$ using a Guildline CTD and a Seatech fluorometer. At every 4 th station, immediately after the water sampling, mesozooplankton were sampled with two $330 \mu \mathrm{m}$ mesh nets mounted on a $1 \mathrm{~m}^{2}$ metal frame equipped with a device allowing opening of the net at a given depth. The nets were fitted with an internal General Oceanic flowmeter and a 31 rigid codend with $80 \mu \mathrm{m}$ mesh apertures. A homemade electronic device was used to monitor the depth and the speed of the net $\left(0.4\right.$ to $\left.0.9 \mathrm{~m} \mathrm{~s}^{-1}\right)$. The trawl was first sent to the bottom of the water column with the net closed and then towed obliquely toward the surface with the ship travelling at 2 to 3 knots. Mesozooplankton were collected from the bottom to $50 \mathrm{~m}$, and from

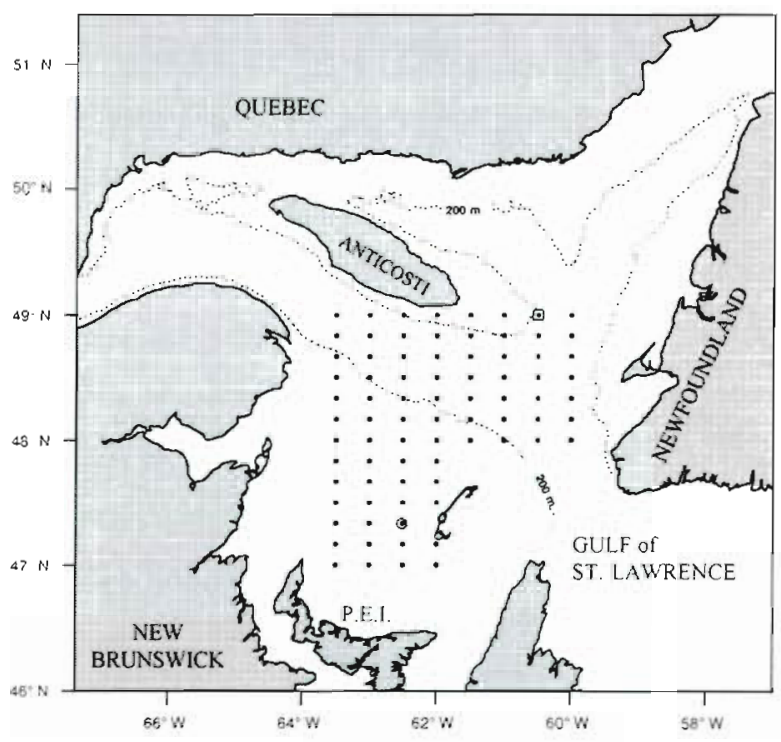

Fig. 1. Sampling stations in the Gulf of St. Lawrence, Canada. (ब) Stn 7 (Bioassay 1); (3) Stn 92 (Bioassay 2) 
$50 \mathrm{~m}$ to the surface (this water layer corresponded approximately to the mixed upper layer and included the subsurface chlorophyll maximum).

Analyses of DMSP and DMS. DMSP and DMS concentrations were determined at each station. All treatments were done in duplicate. For particulate DMSP $\left(\right.$ DMSP $_{p}$ ) determination, two $60 \mathrm{ml}$ subsamples were filtered on Whatman GF/F filters with a low vacuum using a filter tower mounted on a vacuum filtration flask and an electric pump. The filters were then placed in $25 \mathrm{ml}$ serum bottles filled with $24 \mathrm{ml}$ of distilled water and $1 \mathrm{ml}$ of $5 \mathrm{~mol} \mathrm{l}^{-1} \mathrm{KOH}$. For DMSP + free DMS determination, two $25 \mathrm{ml}$ serum bottles were filled with $24 \mathrm{ml}$ of filtrate and $1 \mathrm{ml}$ of $5 \mathrm{~mol} \mathrm{l}^{-1} \mathrm{KOH}$. For free DMS determination, two $25 \mathrm{ml}$ serum bottles were filled with $24 \mathrm{ml}$ of the filtrate and $1 \mathrm{ml}$ of distilled water. All serum bottles were immediately sealed with a Teflon-faced serum cap and kept in the dark at $4^{\circ} \mathrm{C}$ until analysis. DMS samples were analyzed within $4 \mathrm{~h}$ of sampling, while both DMSP samples were measured within the following 2 mo. Experiments conducted in our laboratory have shown that DMSP samples may be stored in the dark at $4^{\circ} \mathrm{C}$ for this period of time without significant variation. DMS was measured on a Varian 3400 gas chromatograph equipped with a flame photometric detector and a Chromosil 330 Teflon column (length $2.4 \mathrm{~m}$, packing length $1.8 \mathrm{~m}$, Supelco Canada Ltd.) following a modified version of the method described by Leck \& Băgander (1988). Samples ( $15 \mathrm{ml}$ ) were sparged with $\mathrm{N}_{2}$ gas ( $30 \mathrm{ml} \mathrm{min}^{-1}$ ) in a heated bubbling chamber $\left(\mathrm{ca} 70^{\circ} \mathrm{C}\right.$ for $2 \mathrm{~min}$ ). The extracted gas then passed through a Nafion drying loop (Perma-Pure Inc.) to remove water vapor and was cryotrapped in a Teflon loop submerged in liquid nitrogen. The Teflon loop was subsequently heated (ca $70^{\circ} \mathrm{C}$ ), releasing the extracted gas onto the $\mathrm{GC}$ column. Using an alkali treatment that cleaves DMSP to produce an equimolar amount of DMS (Challenger \& Simpson 1948), the measured quantity of DMS in filtered samples following $\mathrm{KOH}$ addition therefore represented the total amount of DMSP D $_{d}$ and free DMS. DMSP $_{d}$ was computed as the difference between DMSP $_{\mathrm{d}}+$ DMS and DMS. DMSP was measured directly from the amount of DMS produced by the alkali treatment of the GF/F filters. Standards, prepared from carefully weighed quantities of DMSP (Research Plus Inc.), were analyzed in similar fashion as the DMSP $p$ except that the DMSP crystals were added to the serum bottles instead of the GF/F filters. The limit of quantification for DMS and DMSP were 0.9 and $0.8 \mathrm{nM}$, respectively. The precision of the method for the natural samples was better than $10 \%$ (coefficient of variation).

Analyses of the biological samples. Two $250 \mathrm{ml} \mathrm{sub-}$ samples were filtered on Whatman GF/F filters and extracted with $90 \%$ acetone for 24 h at $4{ }^{\circ} \mathrm{C}$ for the subsequent determination of chlorophyll a (chl a) and phaeopigments using the fluorometric method of Yentsch \& Menzel (1963) as modified by Holm-Hansen et al. (1965). At every 4 th station, two $200 \mathrm{ml}$ subsamples were fixed with either $4 \mathrm{ml}$ of formaldehyde neutralized with hexamethylene $(20 \%)$ or $0.8 \mathrm{ml}$ of acidic Lugol's fixative for later identification and counting of coccolithophores and other phytoplankton cells, respectively, using the Utermöhl technique (magnification of $200 \times$ or $500 \times$; Lund et al. 1958). The size of each phytoplankton species was measured and the cellular volume $\left(\mu^{3}\right)$ was estimated by approximation of cell shapes to geometrical objects (Anonymous 1988). It was assumed that plasma volume was equal to cell volume, although this procedure may introduce an overestimation of the carbon content in diatoms (Strathmann 1967). Some diatoms species were not measured. For these species, we used the cell volumes given in Desilets et al. (1989) The conversion factors used to approximate carbon content were $0.13 \mathrm{pg} \mathrm{C}$ $\mu_{\mathrm{m}}^{-3}$ for armoured Dinophyceae (Smetacek 1977) and $0.11 \mathrm{pg} \mathrm{C} \mu \mathrm{m}^{-3}$ for all other phytoplankton taxa (Strathmann 1967).

At every 4 th station, one $200 \mathrm{ml}$ subsample was also fixed with $0.8 \mathrm{ml}$ of acidic Lugol's fixative for later identification and counting of microzooplankton using an inverted microscope (Lund et al. 1958) following sedimentation of $100 \mathrm{ml}$ subsamples for 3 to $4 \mathrm{~d}$. The carbon biomass of microzooplankton was estimated as described above for phytoplankton using a conversion factor of $0.21 \mathrm{pg} \mathrm{C} \mathrm{mm}^{-3}$ (Ohman \& Snyder 1991).

Mesozooplankton samples were preserved in $4 \%$ borated formaldehyde. Zooplankton abundance data were converted into biomass for the 2 main mesozooplankton species: Calanus finmarchicus and Temora longicornis. C. finmarchicus was sorted into 2 different classes (CI-CIII and CIV-adult). Dry weight (DW, $\mu \mathrm{g}$ ) was calculated according to the length/weight relationship described by the equation $\mathrm{DW}=18.485 X^{2.879}$ for $C$. finmarchicus and DW $=34.986 X^{3.064}$ for $T$. longicornis (Blom et al. 1991). Cephalothorax lengths ( $X$, $\mathrm{mm}$ ) were obtained from the literature (Longhurst 1986, Blom et al. 1991, Karlson \& Båmstedt 1994). The total organic matter was calculated as ash free dry weight (AFDW) assuming that the AFDW represents $93 \%$ of the DW (Bamstedt 1986).

Bioassay experiments. To determine the influence of mesozooplankton on DMSP and DMS net production, 2 bottle experiments were performed on the ship. Bioassays were conducted with Calanus finmarchicus, the dominant mesozooplankter in the Gulf of St. Lawrence, at Stns 7 (Eastern Gulf; Bioassay 1) and 92 (Western Gulf; Bioassay 2) (Fig. 1). For each bioassay, $15 \mathrm{l}$ of water was collected with three $5 \mathrm{l}$ GO-FLO bot- 
tles at the depth of maximum in vivo fluorescence and prescreened through $233 \mu \mathrm{m}$ Nytex mesh. The prescreened seawater was then poured into four 11 gas-tight custom made Pyrex bottles covered with aluminium foil. The bottles were previously silanized to reduce DMS adsorption (Caron \& Kramer 1989). The incubation bottles were equipped with 3 openings: 1 was used to introduce the water and the zooplankton, 1 to collect the DMS samples, and 1 to inject $N_{2}$ gas to facilitate water sampling by creating a positive pressure within the bottle. All openings were closed tight with Teflon seals. C. finmarchicus were collected from the upper mixed layer as previously described except that a bigger ( 8 l) restricted-flow codend was used to prevent damage to the individuals. Mesozooplankton samples were immediately diluted into $4 \mathrm{l}$ glass jars with unfiltered seawater and kept at ca $4^{\circ} \mathrm{C}$ in the dark before sorting of the animals. C. finmarchicus with a minimum prosome length of $3 \mathrm{~mm}$ were sorled from the zooplankton catch and put in 2 of the incubation bottles. Twenty $C$. finmarchicus were placed in each of the 2 treatment bottles for Bioassay 1 and 35 for Bioassay 2 . Two additional bottles filled with prescreened seawater were used as controls. All incubations were done in the dark at a temperature of ca $8^{\circ} \mathrm{C}$. The bottles were gently shaken before each sampling. For DMS analyses, two $24 \mathrm{ml}$ water samples were collected from the incubation bottles at $0,5,10,18$, and $24 \mathrm{~h}$ in Bioassay 1 and at 0, 2, 4, 8, 16 and 24 h in Bioassay 2 . DMS was analyzed as described previously. Subsamples for chl a, phytoplankton and microzooplankton cell counts (only for Bioassay 1) and DMSP $d$ were collected at the beginning $\left(t_{0}\right)$ and at the end $\left(t_{24}\right)$ of the incubation in each bottle and were analyzed as described above. Replication was performed for each variable except for cell counts.

\section{RESULTS}

\section{Hydrography}

The study area was characterized by an east-west salinity and temperature gradient resulting from the extension of the Gaspé Current into the western portion of the sampling grid (Figs. 1 \& 2). The Gaspé Current is a coastal jet resulting from seaward advection of the brackish water of the St. Lawrence Estuary along the Gaspé Peninsula (Benoit et al. 1985). A frontal region, defined by the isohalines 28 to 30 psu, delimited the shallow (28 to $200 \mathrm{~m}$ depth) region influenced by the current, from the deeper (40 to $517 \mathrm{~m}$ ), more saline and colder water of the Gulf (Figs. $1 \& 2$ ). We will refer to these 2 regions as the Eastern and Western Gulf. The biological characteristics of these regions have been previously described in de Lafontaine et al (1991).

\section{Spatial distribution of phytoplankton composition and biomass}

Chl a concentrations ranged from 0.04 to $3.28 \mathrm{\mu g} \mathrm{l}^{-1}$ over the study area but were generally below $0.5 \mu \mathrm{g} \mathrm{l}^{-1}$ (Fig 3, Table 1). Along with phytoplankton groups, the biomass exhibited a general east-west gradient coinciding with the physical gradient described above Maximum phytoplankton biomass and abundance were found in the low salinity and high temperature western region, while the Eastern Gulf was characterized by low chl a and phytoplankton abundance. Ca 107 species and genera were dentified in the phytoplankton assem-

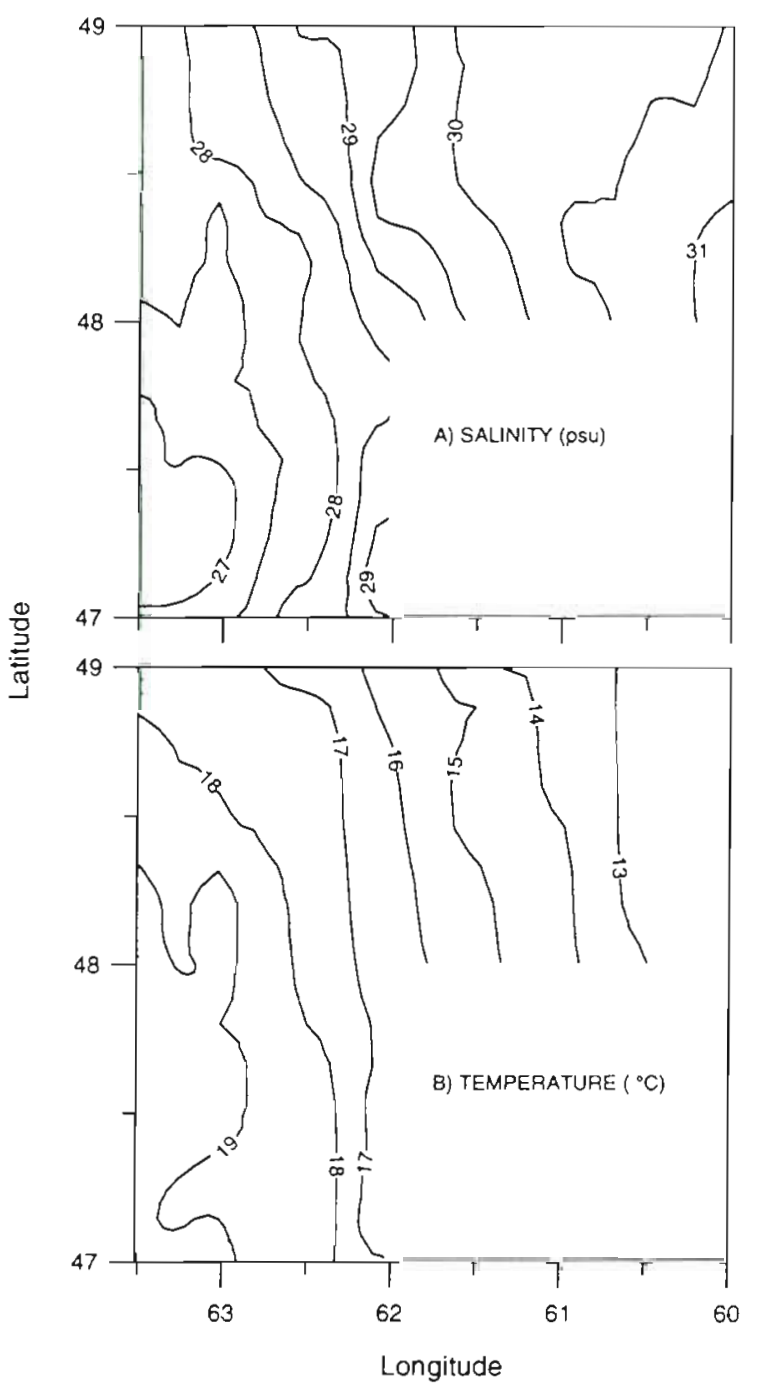

Fig. 2. Surface (A) isohaline and (B) isotherm contours in the Gulf of St. Lawrence in August 1993 

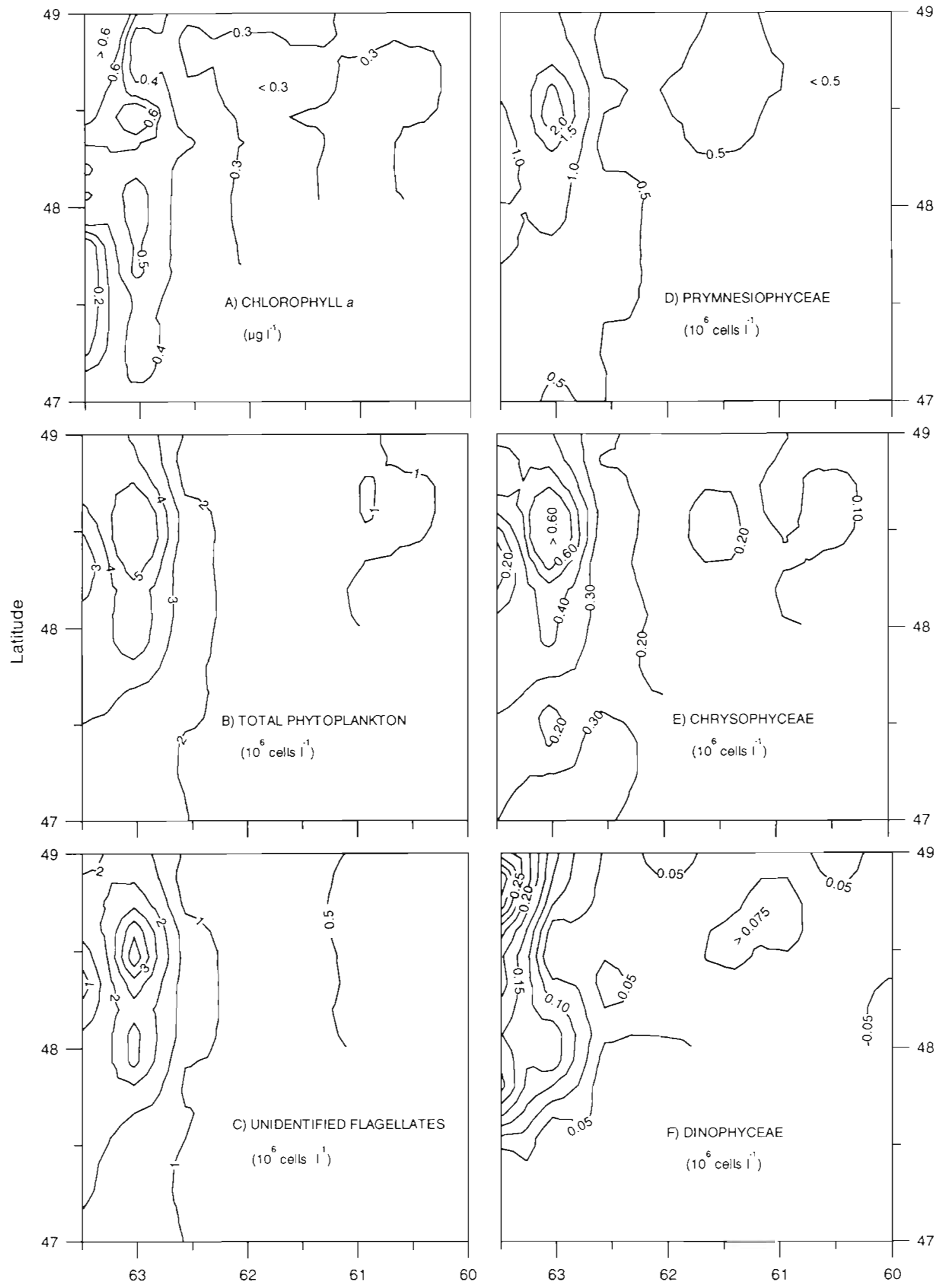

Longitude

Fig. 3. Horizontal distribution of the concentrations of (A) chl $a_{1}$ (B) total phytoplankton, (C) unıdentufied flagellates, (D) Prymnesiophyceae, (E) Chrysophycede, and (F) Dinophyceae measured in the surface waters of the Gulf of St. Lawrence in August 1993 
Table 1. Mean, range, and standard deviation (SD) of chemical and biological variables measured at $1 \mathrm{~m}$ depth, except mesozooplankton abundance which is presented for the upper $50 \mathrm{~m}$ of the water column, in the Gulf of St. Lawrence, Canada, in August 1993, <l.q.. below the limit of quantification

\begin{tabular}{|c|c|c|c|c|c|}
\hline Varıable & $\mathrm{n}$ & Mean & Minimum & Maximum & $\mathrm{SD}$ \\
\hline $\mathrm{DMSP}_{\mathrm{p}}(\mathrm{nM})$ & 79 & 61.2 & 6.1 & 117.0 & 19.9 \\
\hline $\mathrm{DMSP}_{d}(\mathrm{nM})$ & 76 & 9.8 & 1.7 & 23.1 & 4.3 \\
\hline $\mathrm{DMS}(\mathrm{nM})$ & 76 & 3.0 & $<$ l.q. & 8.8 & 2.2 \\
\hline $\mathrm{Chl} a\left(\mu \mathrm{gl}^{-1}\right)$ & 79 & 0.37 & 0.04 & 3.23 & 0.36 \\
\hline Phytoplankton $\left(10^{6}\right.$ cells $\left.\mathrm{I}^{-1}\right)$ & 28 & 2.17 & 0.51 & 8.54 & 1.83 \\
\hline Microzooplankton $\left(10^{3}\right.$ cells $\left.1^{-1}\right)$ & 28 & 43 & 7 & 117 & 35 \\
\hline Mesozooplankton (ind. $\mathrm{m}^{-3}$ ) & 28 & 579 & 37 & 16.38 & 473 \\
\hline
\end{tabular}

blage, although ultraplankton $(<3 \mu \mathrm{m})$ was not counted because of the limits imposed by the method used in our study for phytoplankton enumeration. The phytoplankton assemblage was dominated by unidentified flagellates, Prymnesiophyceae, Chrysophyceae, and Dinophyceae (Fig. 3C, D, E, F). The spatial distribution of the dominant taxa was also characterized by minimum and maximum abundances in the Eastern and Western Gulf, respectively (Fig. 3C, D, E, F). Unidentified flagel-

Table 2. Spearman's rank correlation coefficients between the concentrations of biogenic sulfur and biological variables, and the relative contribution $(\%)$ of the taxa to the total number and total carbon biomass ( $\mathrm{n}=76$ to 79 for chl a and Emiliania huxleyi; $\mathrm{n}=$ 28 for all other variables). $0.01<\mathrm{p} \leq 0.05, \cdots 0.001<\mathrm{p} \leq 0.01, \cdots \mathrm{p} \leq 0.001$. Only taxa contributing to more than $1 \%$ of the total biomass (phytoplankton and microzooplankton) or total abundance (mesozooplankton) are presented. Only results from the mesozooplankton samples collected in the upper $50 \mathrm{~m}$ of the water column are presented

\begin{tabular}{|c|c|c|c|c|c|}
\hline $\begin{array}{l}\text { Class } \\
\text { Species }\end{array}$ & $\mathrm{DMSP}_{p}$ & DMSP $_{d}$ & DMS & $\begin{array}{c}\% \text { total } \\
\text { abundance }\end{array}$ & $\begin{array}{l}\% \text { total } \\
\text { carbon }\end{array}$ \\
\hline Chl a & $0.39 \cdots$ & $0.28^{\circ}$ & 0.04 & & \\
\hline \multicolumn{6}{|l|}{ Phytoplankton } \\
\hline Total & $0.65 \cdots$ & $0.52 \cdots$ & -0.04 & 100.00 & 100.00 \\
\hline Dinophyceae & $0.66^{\cdots} \cdots$ & $0.51^{\cdots}$ & 0.22 & 3.48 & 46.19 \\
\hline Katodinium glaucum & $0.38^{\circ}$ & 0.37 & 0.11 & 0.01 & 1.58 \\
\hline Dinophysis rotundata & $0.57^{\cdots}$ & $0.39^{\circ}$ & 0.15 & $<0.01$ & 2.26 \\
\hline Gyrodinium aureolum & $0.72 \cdots$ & $0.50^{\circ}$ & 0.03 & 0.22 & 4.19 \\
\hline Gymnodinoid sp. $<10 \mu \mathrm{m}$ & $0.55^{\cdots}$ & $0.43^{\circ}$ & 0.19 & 2.19 & 5.36 \\
\hline Ceratium longipes & 0.10 & 0.06 & 0.16 & $<0.01$ & 5.39 \\
\hline Gymnodinoid sp. $20-50 \mu \mathrm{m}$ & $0.50^{\circ}$ & $0.43^{\circ}$ & 0.12 & 0.21 & 17.08 \\
\hline Chrysophyceae & $0.55^{\cdots}$ & $0.43^{\circ}$ & -0.01 & 10.91 & 17.21 \\
\hline Pseudopedinella pyriforme & 0.26 & 0.15 & -0.15 & 0.50 & 1.39 \\
\hline Ochromonas sp. & $0.54^{\cdots}$ & $0.41^{\circ}$ & 0.08 & 5.80 & 4.49 \\
\hline Unidentified chrysophyte $(<15 \mu \mathrm{m})$ & $0.41^{\circ}$ & 0.27 & -0.13 & 2.24 & 7.43 \\
\hline Prymnesiophyceae & $0.70 \cdots$ & $0.63 \cdots$ & -0.11 & 27.90 & 11.02 \\
\hline Emiliania huxleyi & 0.04 & 0.11 & 0.13 & 3.85 & 3.44 \\
\hline Chrysochromulina spp. & $0.69 \cdots$ & $0.58 \cdots$ & -0.12 & 23.06 & 7.03 \\
\hline Unidentified flagellates & $0.54 \cdots$ & $0.42^{\circ}$ & -0.03 & 46.38 & 7.98 \\
\hline Diatoms & $0.47^{\circ}$ & $0.45^{\circ}$ & -0.18 & 1.39 & 6.53 \\
\hline Cryptophyceae & $0.42^{\circ}$ & $0.44^{\circ}$ & -0.04 & 7.08 & 6.26 \\
\hline Leucocryptos manna & $0.47^{\circ}$ & 0.38 & 0.08 & 0.49 & 1.35 \\
\hline Prasinophyceae & $0.66^{\cdots} \cdot$ & $0.65 \cdots$ & -0.11 & 2.86 & 4.81 \\
\hline Pyramimonas sp. & $0.53 \cdots$ & $0.50^{\cdots}$ & -0.11 & 0.83 & 1.41 \\
\hline Hilea sp. & 0.31 & 0.30 & 0.02 & 0.35 & 1.13 \\
\hline \multicolumn{6}{|l|}{ Microzooplankton } \\
\hline Total & 0.19 & 0.34 & -0.21 & 100.00 & 100.00 \\
\hline Ciliates & $0.40^{\circ}$ & $0.37^{\circ}$ & 0.00 & 25.05 & 95.29 \\
\hline Zooflagellates & 0.10 & 0.26 & -0.25 & 74.66 & 3.26 \\
\hline Tintinnıds & 0.05 & -0.10 & 0.21 & 0.29 & 1.45 \\
\hline \multicolumn{6}{|l|}{ Mesozooplankton } \\
\hline Total & & 0.03 & -0.01 & 100.00 & \\
\hline Copepods & & 0.01 & 0.05 & 98.14 & \\
\hline Calanus finmarchicus & & -0.05 & 0.19 & 44.50 & \\
\hline Temora longicornis & & -0.02 & -0.13 & 35.15 & \\
\hline Pseudocalanus minutus & & 0.03 & 0.07 & 13.28 & \\
\hline Calanus hyperboreus & & -0.07 & -0.07 & 1.51 & \\
\hline Centropages hamatus & & 0.04 & 0.11 & 1.22 & \\
\hline Phaeopigments & & 0.09 & 0.12 & & \\
\hline
\end{tabular}


lates, the most abundant group, reached a maximum abundance of $4.1 \times 10^{6}$ cells $\mathrm{l}^{-1}$ in the northwestern part of the sampling grid. Prymnesiophyceae, the second most abundant group, was dominated by Chrysochromulina spp., which reached a maximum abundance of

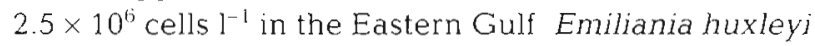
was the second most abundant prymnesiophyte with

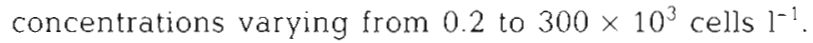
Chrysophyceae (Fig. 3E) and Cryptophyceae (not shown) were respectively the third and the fourth most abundant algal group (Table 2). Dinophyceae (Fig. 3F), which represented only $3 \%$ of the total phytoplankton. abundance, reached a maximum abundance of $0.33 \times$

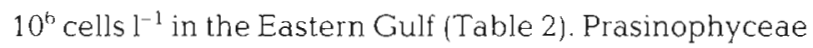
and diatoms represented less than $3 \%$ of total phytoplankton abundance (Table 2). On a biomass basis, Dinophyceae (dinoflagellates) dominated the total phytoplanktonic assemblage, followed by Chrysophyceae, Prymnesiophyceae, unidentified flagellates, diatoms, Cryptophyceae, and Prasinophyceae (Table 2).

\section{Spatial distribution of DMSP and DMS}

DMSP $_{\mathrm{p}}$ concentrations were below $40 \mathrm{nM}$ in the Eastern Gulf and increased westward to reach $117 \mathrm{nM}$ (Fig. 4A, Table 1). DMSP concentrations varied from 1.7 to $23.1 \mathrm{nM}$ (mean $=9.8 \mathrm{nM})$ over the sampling area (Fig. 4B, Table 1). The distribution of DMSP d $_{d}$ was more heterogeneous than the distribution of $\mathrm{DMSP}_{\mathrm{p}}$, but exhibited a comparable increasing gradient toward the west. The spatial distribution of DMS was even more heterogeneous, characterized by 3 zones of maximum concentrations (Fig. 4C) The first zone was located in the southwest part of the sampling grid, the second in the northwest part, and the largest in the Eastern Gulf (Fig. 4C). DMS concentrations varied from below the limit of quantification to $8.8 \mathrm{nM}$, with a mean value of $3.0 \mathrm{nM}$ (Table 1). The east-west gradient in the distribution of $\mathrm{DMSP}_{\mathrm{p}}, \mathrm{DMSP}_{\mathrm{d}}$, and phytoplankton cell numbers followed the salinity and temperature characteristics of the water masses rather well, suggesting a possible hydrodynamic control of the surface patchiness of the plankton community. This idea is reinforced by the significant correlations found between $\mathrm{DMSP}_{\mathrm{p}}$, DMSP $_{d}$, and the physical variables (water temperature and salinity, Table 3). No correlation was found between these physical variables and DMS. DMSP concentration was positively correlated with $\mathrm{DMSP}_{\mathrm{d}}$ but not with DMS. However, DMSP $P_{d}$ concentration was negatively correlated with DMS (Table 3).

$\mathrm{DMSP}_{\mathrm{p}}$ concentration was positively correlated with chl a concentration and the abundance of total phytoplankton, Dinophyceae, Prymnesiophyceae, and Prasinophyceae (Table 2). The dinoflagellate Gyrodinium

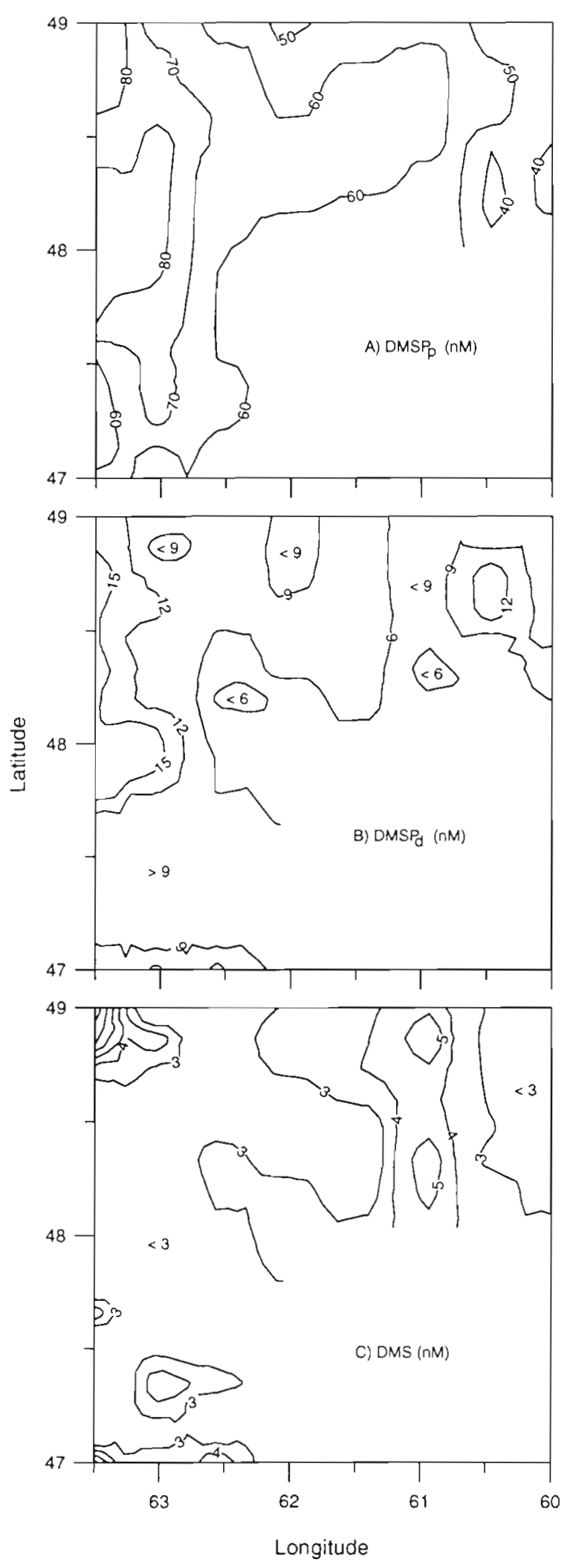

Fig. 4. Horizontal distribution of the concentrations of (A) DMSP $_{p}$ (B) DMSP , and (C) DMS measured in surface waters of the Gulf of St. Lawrence in August 1993 
Table 3. Spearman's rank correlation coefficients between the concentrations of biogenic sulfur and physical variables (DMSP $_{p}$ with water temperature and salunity, $\mathrm{n}=79$ and 75 , respectively, DMSP $d$ and DMS with salinity, $n=72$; others, $n=$

76). $0.01<p \leq 0.05, \cdots 0.001<p \leq 0.01, \cdots p \leq 0.001$

\begin{tabular}{|lcrr|}
\hline & DMSP $_{\mathrm{p}}$ & DMSP $_{\mathrm{d}}$ & DMS \\
\hline DMSP $_{\mathrm{d}}$ & $0.50 \cdots$ & & \\
DMS & 0.10 & $-0.51 \cdots$ & \\
Water temperature & $0.48 \cdots$ & $0.28 \cdots$ & -0.19 \\
Salinity & $-0.56 \cdots$ & $-0.32 \cdots$ & 0.08 \\
\hline
\end{tabular}

aureolum and the prymnesiophyte Chrysochromulina spp. were also strongly correlated with the distribution of $\mathrm{DMSP}_{\mathrm{p}}$. DMSP $\mathrm{DM}_{\mathrm{d}}$ concentration was also positively correlated with chl a concentration (Table 2). As for DMSP $_{p}$, DMSP $_{d}$ concentration was positively correlatcd with all algal groups, particularly with the Prymnesiophyceae, Prasinophyceae, and Chrysochromulina spp. ( $\mathrm{p} \leq 0.001)$. A strong correlation was also found between $\mathrm{DMSP}_{\mathrm{d}}$ and $G$. aureolum. In contrast to DMSP $_{p}$ and DMSP $d$, no correlation was found between the distribution of DMS and chl a or any of the phytoplankton groups or species (Table 2). The prymnesiophyte Emiliania huxleyi was more abundant in the Eastern Gulf (data not shown) where maximum DMS concentrations were measured (Fig. 4C). In spite of this apparent overlap in the distribution of E. huxleyi and DMS, the 2 variables were not significantly correlated (Table 2). In the northwest part of the Gulf, high DMS concentrations (Fig, 4C) coincided with the maximum concentration of Dinophyceae (Fig. 3F).

\section{Spatial distribution of microzooplankton}

The microzooplankton assemblage was composed of 26 species and genera. Microzooplankton abundances were at a maximum in the Western Gulf, with values reaching $0.1 \times 10^{6}$ cells $\mathrm{I}^{-1}$ in the southernmost area of the sampling grid (Fig. 5A). A second patch of microzooplankton was observed in the Eastern Gulf (Fig. 5A, $B)$. Zooflagellates, the most abundant group, represented $75 \%$ of the total microzooplankton abundance (Fig. 5B, Table 1). Zooflagellate abundance showed a distribution pattern almost identical to that of total microzooplankton. Ciliates, the second most abundant group, showed a positive northeast-southwest gradient with values reaching $0.03 \times 10^{6}$ cells $1^{-1}$ in the southwestern part of the grid (Fig. 5C). Tintinnids were found in low abundance $\left(<700\right.$ cells $\left.l^{-1}\right)$ within the sampling grid. On a carbon basis, ciliates largely dominated $(95.3 \%)$ the microzooplankton assemblage followed by zooflagellates $(3.3 \%)$ and tintinnids $(1.5 \%)$

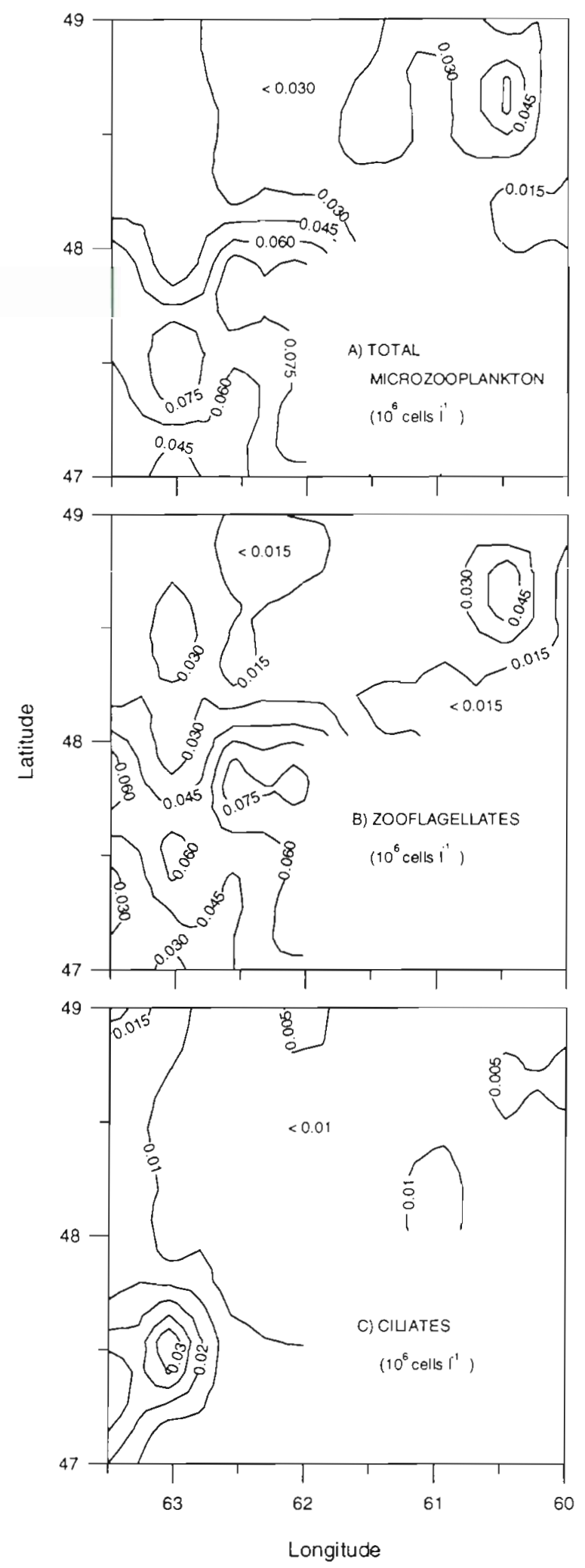

Fig. 5. Horizontal distribution of the abundances of (A) total microzooplankton, (B) zooflagellates, and (C) ciliates measured in surface waters of the Gulf of St. Lawrence in August 1993 
(Table 2). A significant positive correlation was found between the abundance of ciliates, $\mathrm{DMSP}_{\mathrm{p}}$, and DMSP $_{d}$ (Table 2). However, DMS did not correlate with any of the microzooplankton groups (Table 2).

\section{Spatial distribution of mesozooplankton}

The mesozooplankton assemblage was composed of 27 species and genera. Total mesozooplankton abundance in the upper $50 \mathrm{~m}$ of the water column increased progressively from the Eastern Gulf to the southwest part where it reached 1638 ind. $\mathrm{m}^{-3}$ (Fig. 6A). The mesozooplankton assemblage was largely dominated by the copepod Calanus finmarchicus, which represented on average $45 \%$ of the total mesozooplankton abundance (Table 2 ) and reached a maximum biomass

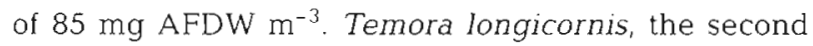
most abundant species, represented $35 \%$ of the total abundance (Table 2) and reached a maximum biomass

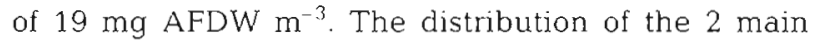
mesozooplankton species was similar to that of the total mesozooplankton (Fig. 6). Pseudocalanus minutus and Calanus hyperboreus were the third and the fourth most abundant species, representing 13 and $2 \%$ of the total abundance, respectively (Table 2). No significant correlation was found between DMSP or DMS and the dominant mesozooplankters (Table 2). Phaeopigment concentration, which can be used as a grazing index (Legendre et al. 1993), showed no significant relationship with DMSP ${ }_{d}$ or DMS (Table 2).

\section{Bioassay experiments}

Bottle incubation experiments with Calanus finmarchicus, the dominant mesozooplankton species, were conducted on the ship to estimate their in situ DMSP $_{d}$ and DMS net production rates. Since replication was good, data from bioassay treatments were combined (Fig. 7). The 2 bioassays were made in the 2 main hydrographic regions characterizing the study area.

Bioassay 1 was conducted in the Eastern Gulf ( $\operatorname{Stn} 7$ ) where the chl a concentration was low. During the $24 \mathrm{~h}$ incubation, the chl a concentration decreased significantly in the control (by $24 \%$; ANOVA, $0.01<\mathrm{p} \leq 0.05$; Fig. 7A) and the treatment bottles (by $38 \%$; ANOVA, $0.01<p \leq 0.05$ ). Grazing by Calanus finmarchicus caused a net decrease of ca $19 \%$ in chl a (ANOVA, $0.001<p \leq 0.01$ ). C. finmarchicus was also responsible for ca 30 and $70 \%$ of the total decrease in phytoplankton and in ciliate cell numbers, respectively (data not shown). Ciliates represented the major prey with $51 \%$ of all carbon ingested by C. finmarchicus in Bioassay 1 ,
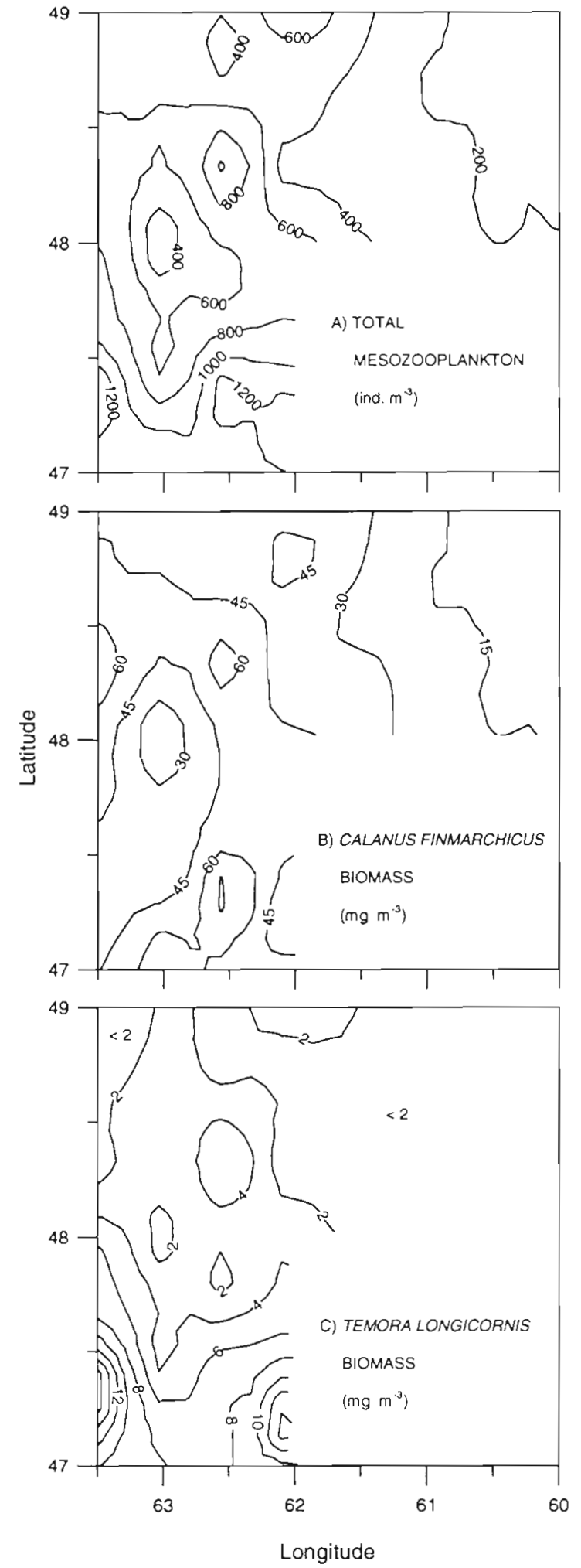

Fig. 6. Horizontal distribution of the abundances of (A) total mesozooplankton and the biomass estimated as ash free dry weight (AFDW) of (B) Calanus finmarchicus, and (C) Temora longicornis measured in the upper $50 \mathrm{~m}$ of the water column of the Gulf of St. Lawrence in August 1993 

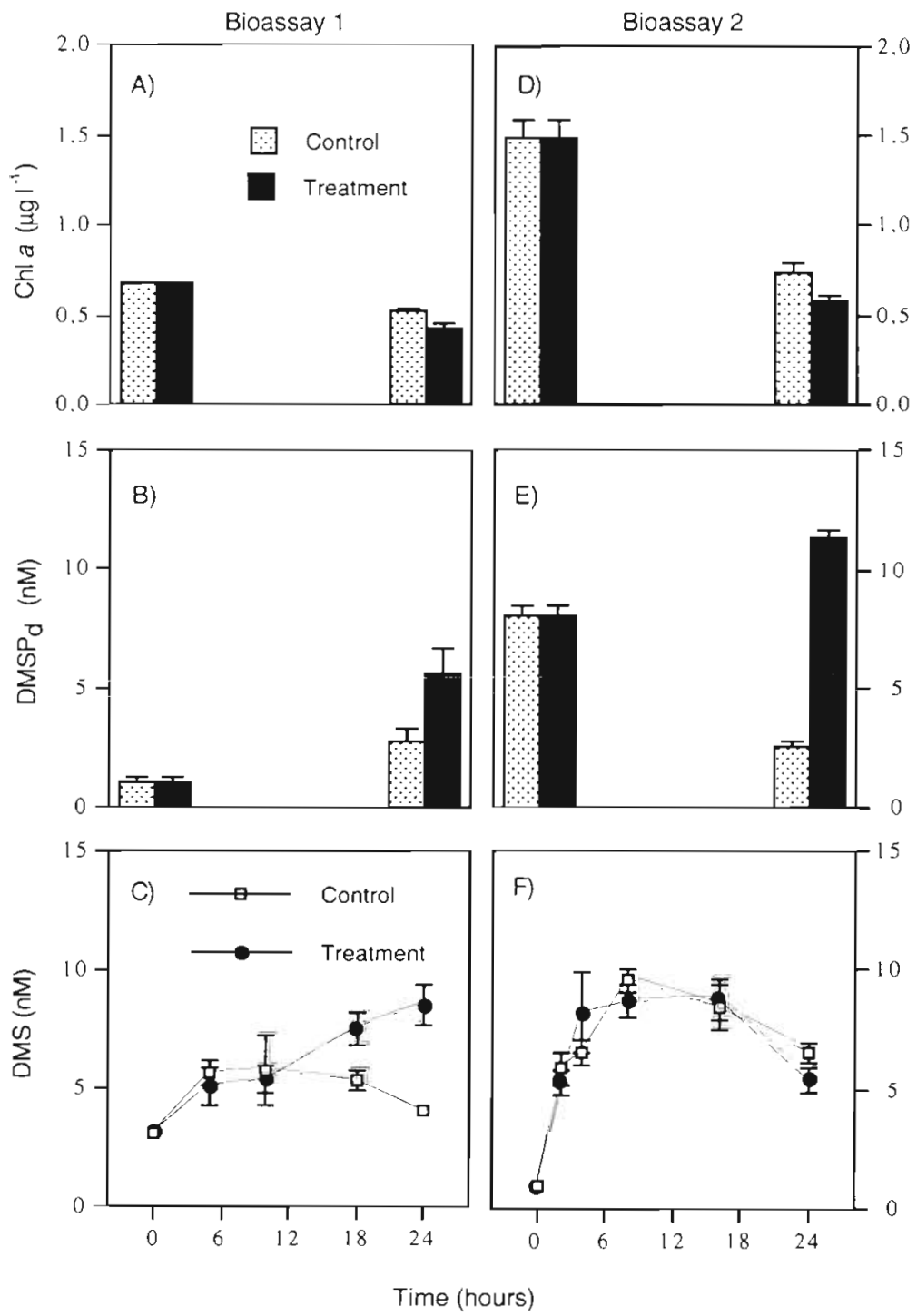

Fig. 7 Temporal variations in the concentrations of chl a ( $A$ and $D$ ), dissolved DMSP ( $\mathrm{B}$ and $\mathrm{E}$ ) and DMS ( $\mathrm{C}$ and $\mathrm{F}$ ) during the 2 bioassay experiments conducted at Stns 7 and 92 with Calanus finmarchicus incubated in seawater prescreened on $233 \mu \mathrm{m}$. Mean values $\pm 1 \mathrm{SE}$

concentrations were the same in the control (ANOVA, p > 0.05), whereas DMS concentration increased from 3.2 to $8.5 \mathrm{nM}$ in the bottles containing the copepods (ANOVA, $0.001<\mathrm{p} \leq 0.01$ ). C. finmarchicus was responsible for a $109 \%$ increase in DMS concentration during the $24 \mathrm{~h}$ experiment.

Bioassay 2 was conducted in the Western Gulf where chl a concentrations were higher than in the Eastern Gulf (Stn 92). The initial chl a concentration in Bioassay 2 was twice that in Bioassay 1 (Fig. $7 \mathrm{~A}, \mathrm{D}$ ). During this bioassay, chl a concentration decreased at a similar rate in the control (by 50\%; ANOVA, p $<0.001$ ) and the treatment bottles (by 61\%; ANOVA, p < $0.001)$. The addition of Calanus finmarchicus had no significant effect on chl a concentration during the incubation (Fig. 7D; ANOVA, p > 0.05). In contrast to Bioassay 1, the decrease in chl $a$ in the control was accompanied by a $69 \%$ de-

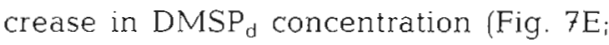
ANOVA, $0.01<p \leq 0.05)$. In the treatment

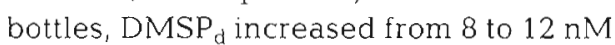
at the end of the experiment (Fig. 7E). This corresponds to a net production rate of ca $0.4 \mathrm{nmol} \mathrm{h}^{-1}$ for $C$. finmarchicus. There was no difference in DMS concentrations between the control and the treatment bottles during Bioassay 2 (Fig. 7F). DMS concentration increased from the limit of quantification to ca $8 \mathrm{nM}$ between 0 and $6 \mathrm{~h}$, remained stable at this concentration until $16 \mathrm{~h}$, and decreased to ca 6 nM toward the end of the experiment.

\section{DISCUSSION}

followed by Dinophyceae with $33 \%$. DMSP concentrations increased from 1.0 to $2.8 \mathrm{nM}$ (ANOVA, $0.01<$ $\mathrm{p} \leq 0.05$ ) in the control during the $24 \mathrm{~h}$ incubation (Fig. $7 \mathrm{~B}$ ). As suggested by the decrease in chl $a$, the increase

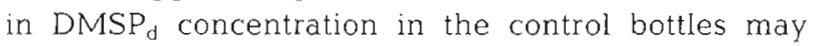
have resulted from microzooplankton grazing or cell autolysis. The addition of $C$. finmarchicus resulted in a net DMSP increase of ca $103 \%$ (Fig 7 B; ANOVA, 0.01 $<\mathrm{p} \leq 0.05$ ). DMS concentration exhibited a similar increase in the control and treatment bottles during the first $10 \mathrm{~h}$ (Fig. $7 \mathrm{C}$ ). Afterwards, DMS concentration started to decline in the control while it continued to increase in the treatment. The initial and final DMS
During this study, phytoplankton concentrations (chl a) were low (mean $=0.37 \mu \mathrm{g} \mathrm{I}^{-1}$ ), reflecting typical mid-summer conditions found in the Gulf of St. Lawrence (Levasseur et al. 1994, Ohman \& Runge 1994). Along with the phytoplankton biomass, concen-

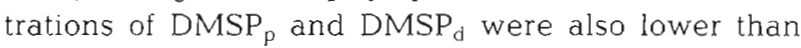
usually reported for estuarine and coastal environ-

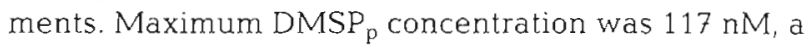
value lower than the maximum values of $160 \mathrm{nM}$ measured along the east coast of the USA (Iverson et al. 1989), $250 \mathrm{nM}$ in the Gulf of Maine (Matrai \& Keller 1993), and $280 \mathrm{nM}$ in the Northeast Atlantic (Malin et al. 1993). However, the mean concentration of $\mathrm{DMSP}_{\mathrm{p}}$ 
in the Gulf of St. Lawrence (61 nM) was higher than in the mid-North Atlantic (11 nM, Bürgemeister et al. 1990 ) and in the same range as that measured around mainland Britain (14 to 287 nM. Turner et al. 1988).

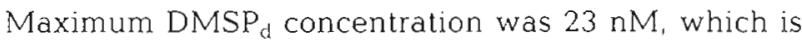
lower than the maximum level measured in near-shore waters of the U.K. (198 nM. Turner et al. 1988) and in the Gulf of Maine (175 nM, Matrai \& Keller 1993). On the other hand, DMS concentrations were in the same range as the values generally observed in coastal areas (1 to $18 \mathrm{nM}$, Iverson et al. 1989; 0 to 6, Leck et al. 1990; 0 to 9 nM, Matrai \& Keller 1993), although our maximum value of $8.8 \mathrm{nM}$ was lower than the maximum values of 24 and $36 \mathrm{nM}$ measured around the British Isles by Holligan et al. (1987) and Turner et al. (1988), respectively.

\section{Co-distribution of phytoplankton, microzoo- plankton, and the DMSP and DMS pools}

Several phytoplankton species or genera apparently contributed to the DMSP pool during this study. The correlation obtained between DMSP $p$ and chl a distributions was expected since the dominant taxa are known to contain high levels of intracellular DMSP (Keller et al. 1989b). The DMSP concentration was significantly correlated with the abundance of Dinophyceae, Prymnesiophyceae, and Prasinophyceae, which represented 46,11 , and $5 \%$ of the total phytoplankton biomass, respectively. Among the numerous species or genera showing significant correlations with DMSP $_{\mathrm{p}}$ Gyrodinium aureolum and Chrysochromulina spp. were the only species to represent a substantial part of the biomass (Table 2). In spite of its relatively low DMSP quota (Keller 1991), G. aureolum has been identified as one of the main sources of DMS in summer around mainland Britain (Turner et al. 1988). Chrysochromulina spp., a species known for its high DMSP quota (Keller 1991), has been previously identified as an important DMSP producer in the Gulf of St. Lawrence in summer (Levasseur et al. 1994).

During our study, DMSP ${ }_{p}$ and DMSP $_{d}$ concentrations were also significantly correlated with ciliates, the dominant microzooplankton in terms of biomass $(95 \%$ of the total biomass). These results suggest that microzooplankton may play a significant role in DMSP cycling in the Gulf of St. Lawrence. Other studies have also shown that microzooplankton can accumulate and metabolize large amounts of DMSP and excrete DMSP $_{\mathrm{d}}$ as well as DMS (Belviso et al. 1990, 1993, Malin et al. 1994, Wolfe et al. 1994).

The strong correlation found between the distribu-

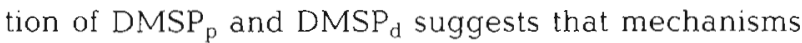
responsible for $\mathrm{DMSP}_{\mathrm{p}}$ production and release in the water are operating on a similar time scale. This indicates a strong dependency between the DMSP $\mathrm{DAn}_{p}$ and

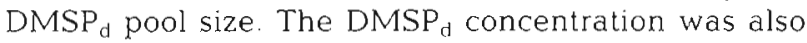
positively correlated with the phytoplankton biomass (chl a) and with the abundance of several phytoplankton species and genera, also indicating a strong coupling between the DMSP producers and the accumulation of dissolved DMSP in the water.

In contrast with the DMSP pools, a less consistent link seems to exist between the surface distribution of phytoplankton and free DMS. A survey of the literature indicates that although many studies have shown significant positive correlations between DMS and chl a (Barnard et al. 1982, 1984, Cline \& Bates 1983, Andreae 1986, Bürgemeister et al. 1990, Kirst et al. 1993, Malin et al. 1993), several others have failed to find such a relationship (Holligan et al. 1987, Turner et al. 1988, Andreae 1990, Leck et al. 1990). In the present study, no significant correlation was found between the surface distribution of DMS and either the DMSP $_{\mathrm{p}}$ pool or the phytoplankton abundance, indicating a spatio-temporal decoupling between DMS production and both phytoplankton growth and $\mathrm{DMSP}_{\mathrm{p}}$ production. This apparent spatial decoupling is not surprising since a time lag of 2 to $10 \mathrm{~d}$ has often been observed between phytoplankton biomass and DMS peaks during mesocosm studies with natural plankton communities (Nguyen et al, 1988, Kwint \& Kramer 1995). The different mechanisms involved in DMS production, such as phytoplankton senescence, zooplankton grazing, and bacterial activity, may explain this decoupling.

\section{Impact of mesozooplankton on $\mathrm{DMSP}_{\mathrm{d}}$ and DMS net production}

Since the first demonstration of the influence of mesozooplankton grazing on DMS production (Dacey \& Wakeham 1986), it has often been assumed that a part of the DMS heterogeneity found in nature results from changes in zooplankton grazing pressure (Holligan et al. 1993). In support of this hypothesis, Leck et al. (1990) found a significant relationship between the distribution of DMS and mesozooplankton over an annual cycle in the Baltic Sea. However, such a relationship is not always observed (Matrai \& Keller 1993).

During this study, we found no significant relationship between the distribution of total mesozooplankton abundance and the concentration of DMSP and DMS. These results suggest that variations in mesozooplankton abundance in the upper $50 \mathrm{~m}$ of the water column by as much as 2 orders of magnitude (range: 37 to 1638 ind. $\mathrm{m}^{-3}$ ) were not sufficient to significantly alter the DMS levels in surface waters. Variations in DMSP 
Table 4. Average (SD in parentheses) rates of chl a ingestion and of DMSP and DMS net production by Calanus finmarchicus as estimated during the 2 bioassay experiments. ANOVA was used to test significant differences between controls and treatments: $\cdot 0.01<p \leq 0.05, \cdots 0.001<p \leq 0.01, \cdots p \leq 0.001$

\begin{tabular}{|c|c|c|c|c|}
\hline Bioassay & $\begin{array}{l}\text { Sampling } \\
\text { station }\end{array}$ & $\begin{array}{l}\text { Ingestion rate } \\
\text { (ng chl } \mathrm{a} \text { ind. }{ }^{-1} \mathrm{~h}^{-1} \text { ) }\end{array}$ & $\begin{array}{l}\text { DMSP }_{d} \text { net production rate } \\
\left(\text { pmol ind }{ }^{-1} \mathrm{~h}^{-1}\right)\end{array}$ & $\begin{array}{l}\text { DMS net production rate } \\
\left.\text { (pmol ind }{ }^{-1} \mathrm{~h}^{-1}\right)\end{array}$ \\
\hline 1 & 7. Eastern Gulf & $0.18(0.10)^{\circ}$ & $5.0(3.6)^{\circ}$ & $7.7(2.9)^{\cdots}$ \\
\hline 2 & 92. Western Gulf & 0 & $8.9(1.1) \cdots$ & 0 \\
\hline
\end{tabular}

and DMS concentrations were also not correlated with the distribution of Calanus finmarchicus and Temora longicornis, the 2 dominant metazoan species. C. finmarchicus and $T$. longicornis are known to perform diurnal vertical migrations characterized by maximum grazing activity during the night near the surface (Tiselius 1988). Consequently, diurnal variations in grazing rate may have obscured the relationship between the abundance of mesozooplankton and the surface concentrations of DMSP ${ }_{d}$ and DMS. To explore this possibility, mesozooplankton and DMS data were divided into 2 subgroups according to the sampling time (5:00 to $21: 00 \mathrm{~h}, 21: 00$ to $5: 00 \mathrm{~h}$ ) and a Spearman rank correlation analysis was performed between mesozooplankton, DMSP ${ }_{d}$, and DMS in each subgroup. Again, we found no statistical evidence of a strong link between mesozooplankton distribution, DMSP $_{d}$, and DMS. Correlations obtained between the abundance of mesozooplankton in the entire water column and these sulfur compounds were also not significant.

The absence of a relationship between the dominant mesozooplankton species and DMSP $d$ or DMS may be due to their low grazing rate on phytoplankton at this time of the year. In the present study, phytoplankton biomass was low and the algal community was dominated by autotrophs smaller than $10 \mu \mathrm{m}$, a poor food source for copepods (Landry 1977). Results from our bioassays confirm that the grazing rate of Calanus finmarchicus on the phytoplankton biomass was low. In the St. Lawrence system, Ohman \& Runge (1994) have reported ingestion rates of C. finmarchicus varying from $0.6 \mathrm{ng}$ chl $a$ ind. ${ }^{-1} \mathrm{~h}^{-1}$ in the low biomass waters of the Gulf $\left(0.3 \mu \mathrm{g} \mathrm{chl} \mathrm{a}^{-1}\right)$ to $35.2 \mathrm{ng}$ chl a ind. ${ }^{-1} \mathrm{~h}^{-1}$ in the productive waters of the Lower St. Lawrence Estuary (ca $14 \mu \mathrm{g} \mathrm{chl} \mathrm{a} \mathrm{l}^{-1}$ ). The chl a ingestion rate measured during Bioassay 1 $\left(0.18 \mathrm{ng}\right.$ chl a ind.$^{-1} \mathrm{~h}^{-1}$. Table 4) was thus comparable to the low rates reported by Ohman \& Runge (1994) for the same area and 2 orders of magnitude lower than their maximum rate. In the phytoplankton-poor waters of the Gulf, the same authors found that at least 70 to $79 \%$ of the diet of C. finmarchicus was composed of heterotrophic prey: mainly ciliates and also dinoflagellates (Dinophyceae) presumed to be heterotrophic. During our study, the abundance of autotrophic prey was even lower than during the study of Ohman \& Runge (1994), although the abundance of ciliates was similar (Table 5)

DMSP and DMS production rates by Calanus finmarchicus were low or non-detectable during our bioassays. Individual maximum DMSP dnd $_{d}$ DMS net production rates were 8.9 and $7.7 \mathrm{pmol}$ ind. ${ }^{-1} \mathrm{~h}^{-1}$, respectively (Table 4 ). These values are low compared to the DMS net production rate of ca $200 \mathrm{pmol}^{\mathrm{ind}} \mathrm{f}^{-1}$ $\mathrm{h}^{-1}$ measured for copepods by Dacey \& Wakeham (1986) and the DMSP + DMS net production rate of 1076 to 4650 pmol ind.$^{-1} \mathrm{~h}^{-1}$ measured for the pteropod Limacina helicina by Levasseur et al. (1994). During our bioassays, most of the $\mathrm{DMSP}_{d}$ and DMS production may have originated from $C$. finmarchicus preying on Dinophyceae, an algal group known for high DMSP content (Keller et al. 1989a, b). In these experiments, dinoflagellates represented the second most important prey for $C$. finmarchicus. However, grazing of $C$. finmarchicus on ciliates, the most important prey, may have also contributed to the observed $\mathrm{DMSP}_{d}$ and DMS production during the bioassays. DMSP accumulated in the microzooplankton may have been ingested by the copepods and partly excreted as DMSP ${ }_{d}$ and/or DMS.

The field extrapolation of DMSP ${ }_{d}$ and DMS net production rates determined during our bioassays pro-

Table 5. Comparison between the mean (range in parentheses) concentration of the main phytoplankton groups and ciliates in the Gulf of St. Lawrence in summer as determined by Ohman \& Runge (1994) and during this study

\begin{tabular}{|c|c|c|c|c|}
\hline Study & $\begin{array}{c}\text { Diatoms } \\
\left(10^{3} \text { cells } 1^{-1}\right)\end{array}$ & $\begin{array}{l}\text { Flagellates } \\
\left(10^{3} \text { cells } 1^{-1}\right)\end{array}$ & $\begin{array}{l}\text { Dinophyceae } \\
\left(10^{3} \text { cells }^{-1}\right)\end{array}$ & $\begin{array}{c}\text { Ciliates } \\
\left.\left(10^{3} \text { cells }\right)^{-1}\right)\end{array}$ \\
\hline $\begin{array}{l}\text { Ohman \& Runge } \\
\text { (1994) }\end{array}$ & $\begin{array}{c}304 \\
(209-347)\end{array}$ & $\begin{array}{c}1625 \\
(452-3901)\end{array}$ & $\begin{array}{c}180 \\
(39-339)\end{array}$ & $\begin{array}{c}9 \\
(7-11)\end{array}$ \\
\hline Present study & $\begin{array}{c}30 \\
(1-286)\end{array}$ & $\begin{array}{c}2066 \\
(515-8336)\end{array}$ & $\begin{array}{c}76 \\
(13-334)\end{array}$ & $\begin{array}{c}7 \\
(4-37)\end{array}$ \\
\hline
\end{tabular}


vides insight into the potential influence of Calanus finmarchicus on the distribution of DMSP $P_{d}$ and DMS. Given the maximum measured abundance of $C$. finmarchicus (601 ind $\mathrm{m}^{-3}$ ) and the maximum $C$. finmarchicus-specific DMSP ${ }_{d}$ and DMS net production rates obtained during the bioassays (Table 4), we calculated that the natural population of $C$. finmarchicus may have increased ambient concentrations of DMSP and DMS at a maximum rate of $5 \mathrm{pmol} \mathrm{l}^{-1} \mathrm{~h}^{-1}$ These rates were probably lower in situ due to DMS photooxidation and sea-to-air ventilation, 2 majors sinks for DMS that were not present in our bottle experiments. In marine environments, DMS photo-oxidation can be as high as $70 \mathrm{pmol} \mathrm{l}^{-1} \mathrm{~h}^{-1}$ (Kieber et al. 1996) and, during our cruise, the mean DMS sea-to-air flux was $200 \mathrm{nmol} \mathrm{m} \mathrm{m}^{-2} \mathrm{~h}^{-1}$ (M. Levasseur et al. unpubl.). This may explain why we observed no significant relationship between the spatial distribution of mesozooplankton and DMS. Thus, at the low mesozooplankton grazing rates measured in this study, the contribution of mesozooplankton to the DMS pool must have been minor. This situation may be typical of the summer period in temperate coastal regions when the microbial food web dominates over the herbivorous food web.

In conclusion, our results show that copepods accounted for minor DMSP $\mathrm{d}_{\mathrm{d}}$ and DMS net production during our cruise, presumably due to low grazing rates. During periods of low phytoplankton biomass, microzooplankton grazing may play a more important role than mesozooplankton in DMS cycling The relative importance of microzooplankton and mesozooplankton grazing on DMS production may vary in time and space according to the prevailing food web, traditional (herbivorous) or microbial. In temperate waters, microzooplankton grazing may be more important during mid-summer and in vertically stable areas characterized by small phytoplankton cells $(<5 \mu \mathrm{m})$ that are mostly exploited by the microbial food web. On the other hand, mesozooplankton grazing probably plays a more important role in DMS production in spring, in frontal regions, and in upwelling areas where the plankton community is dominated by larger phytoplankton cells ( $>5 \mu \mathrm{m}$ ) that are heavily grazed by mesozooplankton (Cushing 1989, Legendre \& Le Fèvre 1989) Future works should attempt to determine the relative efficiency of these 2 main trophic pathways for producing DMS.

Acknowledgements. We are grateful to F. Poudrier, A. Gagné, L. Bérard, D. Lepage, M-L. Dubé, 1. St-Pierre, S. Côté, S. Lessard, F. Roy, F. Blouin, M. Bourgeois, C. Legault, and H. Lambert for their technical assistance. We thank $L$. Legendre, S. de Mora, S. Plourde, and 4 anonymous reviewers for valuable comments on the manuscript. We also thank J.-F. StPierre for supplying a digitized map of the Gulf and L. Devine for editorial corrections. We appreciated the collaboration of the captain and crew members of the NM 'Fogo Isle' G.C. was supported by a post-graduate scholarship from the NSERC (Natural Sciences and Engineering Research Council of Canadal. This research was funded by grants from NSERC to M.L. and M.G., FCAR (Fonds pour la Formation de Chercheurs et l'Aide à la Recherche du Québec) to M.G. and FIRUQAR (Fonds Institutionnel de Recherche, Université du Québec à Rimouskil to M.G., and by financial help from the Institut Maurice-Lamontagne (Ministère des Pêches et des Océans) to M.L. This is a contribution to the research programmes of the Instıtut Maurice-Lamontagne and the Centre océanographique de Rimouski.

\section{LITERATURE CITED}

Andreae MO (1986) The ocean as a source of atmosphernc sulfur compounds. In: Buat-Ménard P (ed) The role of air-sea exchange in geochemical cycling. D Reidel Publ Co, Boston, p 331-362

Andreae MO (1990) Ocean-atmosphere interactions in the global biogeochemical sulfur cycle. Mar Chem 30:1-29

Andreae TW, Andreae MO, Schebeske G (1994) Biogenic sulfur emission and aerosols over the tropical South Atlantic. 1. Dimethylsulfide in seawater and in the atmospheric boundary layer. J Geophys Res 99:22819-22829

Anonymous (1988) Guidelines for the Baltic monjtoring program for the third stage: part D. Biological determinants. Baltic Sea Environmental Proceedings. Baltic Marine Environment Protection Commission-Helsinki, 27D

Bämstedt U (1986) Chemical composition and energy content. In: Corner EDS, O'Hara SCM (eds) The biological chemistry of marine copepods. Clarendon Press, Oxford, p 4-50

Barnard WR. Andreae MO, lverson L (1984) Dimethylsulfide and Phaeocystis pouchetir in the southeastern Bering Sea. Cont Shelf Res 3:103-113

Barnard WR, Andreae MO, Watkins WE (1982) The flux of dimethylsulfide from the ocean to the atmosphere. J Geophys Res 87:8787-8793

Bates TS, Kiene RP, Wolfe GV, Matrai PA, Chavez FP, Buck KR, Blomquist BW, Cuhel RL (1994) The cycling of sulfur in surface seawater of the northeast Pacific. J Geophys Res 99:7835-7843

Belviso S, Buat-Ménard P, Putaud JP, Nguyen BC, Claustre $\mathrm{H}$, Neveux J (1993) Size distribution of dimethylsulfoniopropionate (DMSP) in areas of the tropical northeastern Atlantic Ocean and the Mediterranean Sea. Mar Chem 44: $55-71$

Belvıso S, Kim SK, Rassoulzadegan F, Krajka B, Nguyen BC, Mihalopoulos N. Buat-Ménard P (1990) Production of dimethylsulfonium propionate (DMSP) and dimethylsulfide (DMS) by a microbial food web. Limnol Oceanogr 35: $1810-1821$

Benoit J, El-Sabh MI, Tang CL (1985) Structure and seasonal characteristics of the Gaspé Current. J Geophys Res 90: $3225-3236$

Blom G, Otterå H, Svăsand T, Kristiansen TS, Serigstad B (1991) The relationship between feeding conditions and production of cod fry (Gadus morhua L.) in a semienclosed marne ecosystem in western Norway, illustrated by use of a consumption model. ICES Mar Sci Symp 192: $176-189$

Brimblecombe P, Shooter D (1986) Photo-oxydation of dimethylsulphide in aqueous solution. Mar Chem 19: 343-353

Bürgemeister S, Zimmermann RL, Georgil HW, Bingemer HG, Kirst GO, Janssen Mr Ernst W (1990) On the biogenic 
ongin of dimethylsulfide: relation between chlorophyl, ATP, organismic DMSP, phytoplankton species, and DMS distribution in Atlantic surface water and atmosphere. J Geophys Res 95:20607-20615

Cantonı GL. Anderson DG (1956) Enzymatic cleavage of dimethylpropiothetin by Polysiphonia lanosa. J Biol Chem 222:171-1.77

Caron F, Kramer JR (1989) Gas chromatographic determunation of volatile sulfıdes at trace levels in natural treshwaters. Anal Chem 61:114-11.8

Challenger F, Simpson MI (1948) Studies on bılological methylation. Part XII. A precursor of the dimethylsulfide evolved by Polysiphonia fastigiata. Dimethyl 2-carboxyethylsulphonium hydroxide and its salts. J Chem Soc 3:1591-1597

Charlson RJ, Lovelock JE, Andreae MO, Warren SG (1987) Oceanic phytoplankton, atmospheric sulphur, cloud albedo and climate. Nature 326:655-661

Cline JD, Bates TS (1983) Dimethyl sulfide in the equatorial Pacific Ocean: a natural source of sulfur to the atmosphere. Geophys Res Lett 10:949-952

Cushing DH (1989) A difference in structure between ecosystems in strongly stratified waters and in those that are only weakly stratificd. I Plankton Res 11:1-13

Dacey JW, Wakeham SG (1986) Oceanic dimethylsulfide: production during zooplankton grazing on phytoplankton. Science 233:1314-1316

de Lafontaine Y, Demers S, Runge J (1991) Pelagic food web interactions and productivity in the Gulf of St. Lawrence: a perspective. In: Therriault JC (ed) The Gulf of St. Lawrence: small ocean or big estuary? Can Spec Publ Fish Aquat Sci 113:99-123

Desilets H, Painchaud J, Therriault JC (1989) Abondance, composition spécifique et biomasse du phytoplancton de l'Estuaire moyen du Saint-Laurent. Rapp Tech Can Sci Halieut Aquat 1698:vil

Hegg DA, Radke LF, Hobbs PV (1991) Measurements of aitken nuclei and cloud condensation nuclei in the marine atmosphere and their relation to the DMS-Cloud-Climate hypothesis. J Geophys Res 96:18727-18733

Holligan PM, Fernández E, Aiken J, Balch WM, Boyd P, Burkill PH, Finch M, Groom SB, Malin G, Muller K, Purdie $D A$, Robinson $C$, Trees $C C$. Tumer SM, van der Wal $P$ (1993) A biogeochemical study of the coccolithophore, Emiliania huxleyi, in the North Atlantic. Global Biogeochem Cycles 7:879-900

Holligan PM, Turner SM, Liss PS (1987) Measurement of dimethyl sulphide in frontal regions. Cont Shelf Res 7 : $213-224$

Holm-Hansen O, Lorenzen CJ, Holmes RN, Strickland JS (1965) Fluorometric determination of chlorophyll. J Cons Int Explor Mer 30:3-15

Iverson RL, Nearhoof FL, Andreae MO (1989) Production of dimethylsulfonium propionate and dimethylsulfide by phytoplankton in estuarine and coastal waters. Limnol Oceanogr 34:53-67

Karlson K, Bămstedt U (1994) Planktivorous predation on copepods. Evaluation of mandible remains in predator guts as a quantitative estimate of predation. Mar Ecol Prog Ser 108:79-89

Keller MD (1991) Dimethyl sulfide production and marine phytoplankton: the importance of species composition and cell size. Biol Oceanogr 6:375-382

Keller MD, Bellows WK, Guillard RRL (1989a) Dimethylsulfide production and marine phytoplankton: an additional impact of unusual blooms. In: Cosper EM, Bricelj VM, Carpenter EJ (eds) Novel phytoplankton blooms. Springer-Verlag, Berlin, p 101-115
Keller MD, Bellows WK, Guillard RRL (1989b) Dimethyl sulfide production in marine phytoplankton. In: Saltzman ES, Cooper WJ (eds) Biogenic sulfur in the environment. American Chemical Society, Washington DC, p 167-182

Kieber DJ, Jiao J, Kiene RP, Bates TS (1996) Impact of dimethysulfide photochemistry on methyl sulfur cycling in the equatorial Pacific Ocean. J Geophys Res 101: $3715-3722$

Kiene RP (1992) Dynamics of dimethyl sulfide and dimethylsulfoniopropionate in oceanic water samples. Mar Chem $37: 29-52$

Kiene RP, Bates TS (1990) Biological removal of dimethyl sulphide from sea water. Nature 345:702-705

Kıene RP, Service SK (1991) Decomposition of dissolved DMSP and DMS in estuarıne waters: dependence on temperature and substrate concentration. Mar Ecol Prog Ser $76: 1-11$

Kirst GO, Wanzek M, Haase R. Rapsomanikis S, de Mora S, Schebeske G. Andreae MO (1993) Ecophysiology of ice algae (Antarctica): dimethylsulfoniopropionate content and release of dimethylsulfide during ice melt. In: Restelli G, Angeletti G (eds) Dimethylsulphide: oceans, atmosphere, and climate. Kluwer Academic Publishers, Brussels, p 23-36

Kwint RLJ, Kramer KJM (1995) Dimethylsulphide production by plankton communities. Mar Ecol Prog Ser 121:227-237

Landry MR (1977) A review of important concepts in the trophic organization of pelagic ecosystems. Helgol Meeresunters $30: 8-17$

Lawrence MG (1993) An empirical analysis of the strength of the phytoplankton-dimethylsulfide-cloud-climate feedback cycle. J Geophys Res 98:20663-20673

Leck C, Bågander LE (1988) Determination of reduced sulfur compounds in aqueous solutions using gas chromatography flame photometric detection. Anal Chem 60: $1680-1683$

Leck C, Larsson U, Bågander LE, Johansson S, Hajdu S (1990) Dimethyl sulfide in the Baltic sea: annual variability in relation to brological activity. J Geophys Res 95: $3353-3363$

Legendre L, Gosselin M, Hirche HJ, Kattner G, Rosenberg G (1993) Environmental control and potential fate of sizefractionated phytoplankton production in the Greenland Sea ( $75^{\circ}$ N). Mar Ecol Prog Ser 98:297-313

Legendre L, Le Fèvre J (1989) Hydrodynamical singularities as controls of recycled versus export production in oceans. In: Berger WH, Smetacek VS, Wefer G (eds) Productivity of the oceans: present and past. Wiley, Chichester, $p$ 49-63

Levasseur M, Keller MD, Bonneau E, D'Amours D, Bellows WK (1994) Oceanographic basis of a DMS-related atlantic cod (Gadus morhua) fishery problem: blackberry feed. Can J Fish Aquat Sci 51:881-889

Longhurst AR (1986) Instar increments in copepod growth Can. J Fish Aquat Sci 43:1671-1674

Lund JWG, Kipling C, Le Cren ED (1958) The inverted microscope method of estimating algal numbers and the statist1cal basis of estimation by counting. Hydrobiologia 11 $143-178$

Malin G, Liss PS, Turner SM (1994) Dimethyl sulfide: production and atmospheric consequences. In: Green JC, Leadbeater BSC (eds) The haptophyte algae. Clarendon Press, Oxford, p 303-320

Malin G, Turner S, Liss P, Holligan P, Harbour D (1993) Dimethylsulphide and dimethylsulphoniopropionate in the nor theast Atlantic during the summer coccolithophore bloom. Deep Sea Res 40:1487-1508 
Matrai PA, Keller MD (1993) Dimethylsulfide in a large-scale coccolithophore bloom in the Gulf of Maine. Cont Shelf Res 13:831-843

Matrai PA, Keller MD (1994) Total organic sulfur and dimethylsulfoniopropionate in marine phytoplankton: intracellular variations. Mar Biol 119:61-68

Nguyen B, Belviso S, Mihalopoulos N (1988) Dimethyl sulfıde production during natural phytoplanktonic blooms. Mar Chem 24:133-141

Ohman MD, Snyder RA (1991) Growth kinetıcs of the omnivorous oligotrich clliate Strombidium sp. Limnol Oceanogr 36:922-935

Ohman MD, Runge JA (1994) Sustanned fecundity when phytoplankton resources are in short supply: omnivory by Calanus finmarchicus in the Gulf of St. Lawrence. Limnol Oceanogr 39:21-36

Smetacek V (1977) Die Sukzession des Phytoplanktons in der westlichen Kieler Bucht. Dissertation, University of Kiel

Stefels J, van Boekel WHM (1993) Production of DMS from dissolved DMSP in axenic cultures of the marine phytoplankton species Phaeocystis sp. Mar Ecol Prog Ser 97:11-18

Strathmann RR (1967) Estimating the organic carbon content of phytoplankton from cell volume or plasma volume. Limnol Oceanogr 12:101-108

Thompson AM, Esaias WE, lverson RL (1990) Two approaches to determining the sea-to-air flux of dimethyl sulfide: satellite ocean color and a photochemical model with atmospheric measurements. J Geophys Res 95: 20551-20558

This article was submitted to the editor
Tiselius P (1988) Effects of diurnal feeding rhythms, species composition and vertical migration on the grazing impact of calanoid copepods in the Skagerrak and Kattegat. Ophelia 28:215-230

Turner SM, Malin G, Liss PS, Harbour DS, Holligan PM (1988) The seasonal variation of dimethyl sulfide and dimethylsulfoniopropionate concentrations in near-shore waters. Limnol Oceanogr 33:364-375

Vairavamurthy A. Andreae MO, Iverson RL (1985) Biosynthesis of dimethylsulfide and dimethylpropiothetun by Hymenomonas carterae in relation to sulfur source and salinity varıations. Limnol Oceanogr 30:59-70

Wakeham SG. Howes BL, Dacey JWH (1987) Biogeochemistry of dimethylsulfide in a seasonally stratified coastal salt pond. Geochim Cosmochim Acta 51:1675-1684

Wolfe GV, Kiene RP (1993) Radioisotope and chemical inhibitor measurements of dimethyl sulfıde consumption rates and kinetics in estuarine waters. Mar Ecol Prog Ser 99:261-269

Wolfe GV, Sherr EB, Sherr BF (1994) Release and consumption of DMSP from Emiluania huxleyi durng grazing by Oxyrrhis marina. Mar Ecol Prog Ser 111:111-119

Yentsch CS, Menzel DW (1963) A method for the determination of phytoplankton chlorophyll and phaeophytin by fluorescence. Deep Sea Res 10:221-231

Zeyer J, Eicher P, Wakeham SG, Schwarzenbach RP (1987) Oxidation of dimethyl sulfide to dimethyl sulfoxide by phototrophic purple bacteria. Appl Environ Microbiol 53: $2026-2032$

Manuscript first received: October 4, 1995

Revised version accepted: June 20, 1996 